\title{
KINERJA PELAYANAN RUMAH SAKIT UMUM DAERAH
}

\author{
Petrus Atong
}

\author{
Fakultas Ilmu Sosial dan Ilmu Politik Universitas Kapuas Sintang \\ Jln.Oevang Oeray Nomor: 92 Baning Kota Sintang \\ Email:atong-petrus@gmail.com
}

\begin{abstract}
Abstrak: Pada dasarnya penelitian ini menyoroti masalah kinerja pelayanan RSUD terhadap pelayanan publik di kabupaten Sintang. Fokus masalahnya ada dua hal : 1) kualitas pelayanan administratif di RSUD kabupaten Sintang. 2) kualitas pelayanan medis di RSUD kabupaten Sintang. Tujuan yang ingin dicapai dalam penelitian ini pada umumnya selain ingin mengetahui secara cermat, tetapi juga memberikan analisa tentang kualitas pelayanan RSUD kabupaten Sintang.Metode penelitian yang dipergunakan dalam penelitian ini adalah metode deskriptif dengan pendekatan studi kasus, yang menjadi subyek penelitian adalah Direktur RSUD dan Kasi Pelayanan RSUD. Instrumen (alat) pengumpul data pedoman wawancara dan pedoman observasi. Adapun kesimpulan dari penelitian ini adalah : kinerja pelayanan RSUD kabupaten Sintang terhadap pelayanan publik sudah baik.
\end{abstract}

Kata Kunci: Kinerja, Pelayanan, RSUD

Salah satu bidang pelayanan yang menjadi prioritas pemerintah Indonesia ini adalah bidang kesehatan. Hal ini dikarenakan dibidang kesehatan masih menjadi masalah yang cukup serius dihadapi masyarakat Indonesia. Umumnya masalah kesehatan itu terfokus pada masih rendahnya derajat kesehatan masyarakat yang dinilai dari indikator tingkat kematian, pengidapan berbagai penyakit dan pola hidup yang kurang baik. Disaat yang sama dimulai tahun 1999 ketika pembangunan nasional diarahkan pada peningkatan kualitas sumber daya manusia (SDM), bidang kesehatan menjadi salah satu indikator dari peningkatan SDM tersebut. Oleh karena itu, pemerintah berupaya lebih mengembangkan dan meningkatkan pelayanan dibidang kesehatan kepada masyarakat diseluruh Indonesia.

Di kabupaten Sintang, bidang kesehatan adalah salah satu masalah pokok yang dihadapi pemerintah daerah. Oleh karenanya, pelaksanaan pembangunan daerah kabupaten Sintang diarahkan pada upaya peningkatan kualitas manusia seutuhnya, yang salah satu indikator adalah peningkatan derajat kesehatan masyarakat. Bentuk dari upaya yang dilakukan pemerintah daerah untuk meningkatkan derajat kesehatan tersebut adalah peningkatan sarana dan prasarana kesehatan serta peningkatan kualitas pelayanan kesehatan.

Adapun salah satu prasarana atau fasilitas yang dimiliki pemerintah daerah kabupaten Sintang untuk melaksanakanfungsi pelayanan kesehatan kepada masyarakat adalah rumah sakit umum daerah (RSUD) kaupaten Sintang yang berada dikota Sintang. Sebagai perangkat dearah RSUD kabupaten Sintang berkedudukan sebagai unit pelaksana teknis daerah (UPTD). Secara garis besar fungsi RSUD kabupaten Sintang adalah memerikan pelayanan, baik pelayanan dari segi administratif maupun pelayanan dari segi medis kepada masyarakat. Pelayanan dari segi administratif dapat berupa pelayanan ketatausahaan, yang meliputi pendaftaran pasien, pemberian dan pengambilan obat, pembayaran biaya medis dan sebagainya. Sedangkan pelayanan dari segi medis dapat berupa perlakuan medis yang diberikan tenaga kesehatan seperti Dokter, perawat, bidan, mantri dan petugas medis lainnya kepada masyarakat yang membutuhkan pelayanan medis.

Dengan mengemban fungsi pelayanan yang memegang dua nilai seperti diatas, RSUD kabupaten Sintang dituntut dapat memberikan pelayanan yang berkualitas. Sebab dengan pelayanan yang berkualitas akan memberikan citra yang baik sehingga tingkat kepercayaan masyarakat semakin tinggi. Efek positif yang akan muncul dari citra baik itu adalah semakin meningkatnya jumlah pelanggan dalam masyarakat sehingga akan berdampak kepada peningkatan pendapatan RSUD itu sendiri. Peningkatan kualitas pelayanan di RSUD kabupaten Sintang ini juga merupakan sebuah konsekuensi logis dari perkembangan dunia yang diliputi persaingan yang semakin tajam diberbagai bidang termasuk hal pelayanan kesehatan. Karena dalam lingkup lokal. Dikota Sintang pada khususnya telah ada rumah sakit swasta, yaitu Rumah Sakit Sungai Ukoi yang dapat menjadi pesaing lokal bagi RSUD kabupaten Sintang. Sedangkan dalam lingkup regional (Kalimantan Barat) dan nasional persaingan antar rumah sakit baik pemerintah atau swasta semakin tinggi dengan berbagai penawaran pelayanan yang semakin berkualitas dan maju. Disisi lain yang tak kalah pentingnya, bahwa ditengah masyarakat saat ini telah tumbuh pemahaman akan arti pentingnya kesehatan yang baik sehingga 
menuntut tingkat kualitas pelayanan kesehatan yang tinggi pula. Oleh karena itu, mengacu kepada pemahaman yang diungkapkan diatas, tidak dapat dipungkiri bahwa upaya peningkatan kualitas pelayanan di RSUD kabupaten Sintang merupakan sesuatu yang penting untuk dilakukan.

Sebagai langkah awal untuk melakukan upaya peningkatan kualitas pelayanan kesehatan di RSUD kabupaten Sintang adalah dengan menilai secara obyektif pelaksanaan pelayanan kesehatan yang telah diberikan RSUD kabupaten Sintang kepada masyarakat selama ini. Hal ini dikarenakan melalui penilaian tersebut diperoleh berbagai informasi penting, seperti tingkat kualitas pelayanan telah tercapai, berbagai kendala dan hambatan yang dihadapi, serta upaya yang sebaiknya diambil untuk mengatasinya serta mengidentifikasi faktor pendukung yang diperlukan RSUD dalam meningkatkan kualitas pelayanannya. Berbagai informasi ini akan menjadi dasar atau pedoman dalam penyusunan rencana aksi dan strategi dalam kinerja pelayanan di RSUD kabupaten Sintang.

Pada dasarnya dalam penelitian ini menyoroti tentang kinerja pelayanan RSUD kabupaten Sintang, oleh karena itu sangat diperlukan memahami konsep kualitas kerja. Untuk menelaah konsep kualitas kerja sebelumnya akan dipaparkan masing-masing tentang makna kualitas dan makna kerja yang membentuk konsep tersebut. Istilah kualitas menurut Gaspersz (2001 : 5) mengandung dua makna, yaitu : sejumlah keistimewaan produk, baik keistimewaan langsung maupun keistimewaan atraktif yang memenuhi keinginan pelanggan dan dengan demikian memberikan kepuasan atas penggunaan produk itu. segala sesuatu yang bebas dari kekurangan atau kerusakan. Sedangkan konsep kerja pada umumnya adalah aktivitas yang berpola dilakukan oleh seseorang atau sekelompok orang yang terikat dalam aturan dan mekanisme tertentu untuk mencapai tujuan tertentu.

Dari penertian kualitas dan penertian kerja diatas, dapat dipahami bahwa kualitas kerja pada dasarnya merupakan tingkat keistimewaan produk (baik barang dan jasa) yang dihasilkan melalui aktivitas yang berpola dari seseorang atau sekelompok orang untuk mencapai tujuan tertentu. Kualitas kerja tersebut dapat berwujud ketepatan dalam bekerja, kecepatan dalam bekerja atau pula optimalisasi dalam mencapai tujuan dari pekerjaan tersebut. Menurut Swiss pada dasarnya manajemen mutu terpadu adalah komitmen yang penuh kesungguhan untuk meningkatkan kualitas, berjangka panjang dan membutuhkan peralatan danteknik-teknik tertentu (dalam Salusu, 2000 : 456). Dengan demikian, manajemen mutu terpadu adalah kegiatan manajerial yang secara total atau keseluruhan diarahkan pada pencapaian mutu secara optimal.
Menurut Swiss (dalam Salusu, $2000: 456$ ) konsep manajemen mutu terpadu meliputi beberapa hal berikut ini : Konsumen adalah penentu kualitas akhir. Kualitas harus dikembangkan pada awal proses produksi dan tidak ditambahkan kemudian. Mencegah keanekaragaman adalah kunci untuk menawarkan produk yang berkualitas. Kualitas dari orang-orang yang bekerja dalam sistem, bukan dari usaha perorangan. Kualitas mempersyaratkan perbaikan masukan dan proses secara kontinyu. Perbaikan kualitas menuntut peran serta semua karyawan dalam organisasi. Kualitas menuntut komitmen organisasi secara terpadu. Dalam konteks kehidupan organisasi, untuk melaksanakan sesuatu pekerjaan, tentunya memerlukan adanya pedoman, agar pekerjaan tersebut dapat berjalan secara tertib, benar, berkualitas dan mencapai tujuannya secara lebih baik.

Berikut ini beberapa pedoman untuk bekerja yang lebih baik dan berkualitas seperti yang disarankan oleh Mali(dalam Kumorotomo, 2001 :332) : Selalu memiliki gagasan yang lebih baik. Penyelesaian tugas yang lebih baik.Memahami pekerjaan yang lebih baik. Mampu bergaul dengan atasan maupun bawahan. Selalu menyukai pekerjaan apapun. Memiliki tingkat kehadiran yang baik. Selalu tabah dan tidak suka mengeluh. Memiliki kebiasaan kerja yang baik. Selalu cepat mempelajari sesuatu yang baru.

Khususnya dikehidupan organisasi publik yang fungsi utamanya memberikan pelayanan publik, bekerja dituntut mencapai produktifitas yang tinggi. Dalam hubungannya dengan itu, menurut American Society for Public Administration (dalam Kumorotomo, 2001 : 347) terdapat kode etik administrasi modern dalam memberikan pelayanan publik, yaitu : Pelayanan kepada masyarakat adalah diatas pelayanan kepada diri sendiri. Rakyat adalah berdaulat dan mereka yang bekerja dalam instansi pemerintah pada akhirnya bertanggung jawab kepada rakyat. Hukum mengatur semua tindakan instansi pemerintah. Manajemen yang efisien dan efektif adalah dasar bagi administrasi negara. Sistem penilaian kecakapan, kesempatan yang sama, dan asas-asas itikad baik akan didukung, dijalankan dan dikembangkan. Perlindungan terhadap kepercayaan rakyat adalah sangat penting. Pelayanan kepada masyarakat menuntut kepekaan khusus dengan ciri sifat keadilan, keberanian, kejujuran, persamaan, kopetensi dan kasih sayang. Hati nurani memegang peranan penting dalam memilih arah tindakan. Tidak hanya terliat dalam mencegah yang salah, tetapi juga mengusahakan yang benar melalui pelaksanaan tanggung jawab dengan penuh semangat dan tepat pada waktunya.

Tugas pelayanan publik merupakan tugas yang berat disandang oleh pemerintah. Oleh karena itu diperlukan adanya manajemen pelayanan publik/ 
masyarakat. Dalam kehidupan masyarakat yang kompleks juga sehingga menuntut pelayanan pemerintah yang baik dan berkualitas. Pada kondisi inilah sebenarnya pemerintah mengalami dilema dalam pemberian pelayanan publik yang berkualitas. Sebab masalah dan kebutuhan masyarakat yang dihadapi beraneka ragam. Selain itu tingkat kepuasan masyarakat yang dilayani juga berbeda-beda sehingga selalu ada yang tidak merasa puas dalam pelayanan. Sementara itu, disaat bersamaan pemerintah mengalami banyak keterbatasan, baik dari segi pendanaan, kelembagaan, personil atau keahlian.

Dilingkungan organisasi publik (birokrasi pemerintah) tugas dan fungsi pelayanan publik memerlukan standar kinerja. Hal ini menjadi penting karena selain akan menjadi ukuran terhadap pelaksanaan fungsi organisasi publik dalam memberikan pelayanan publik kepada masyarakat, tetapi juga akan menjadi bahan evaluasi terhadap pelaksanaan tugas pelayanan tersebut. Untuk yang terakhir ini, organisasi publik akan memperoleh berbagai informasi tentang berbagai hal yang perlu untuk ditingkatkan dan atau ditinggalkan dalamhubungannya dengan fungsi pemberian pelayanan publik kepada masyarakat. Sehingga upaya meningkatkan kualitas pelayanan publik akan dapat dilakukan secara efektif, efisien dan menyeluruh.

Dalam upaya agar aparatur-aparatur pemerintah dapat memberikan pelayanan prima kepada masyarakat, maka kantor Menteri Pendayagunaan Aparatur Negara (MENPAN) telah mengeluarkan pedoman tata laksana pelayanan umum yang tertuang dalam keputusan Menpan Nomor 81 tahun 1993. Pedoman tersebut merupakan acuan umum bagi instansi pemerintah dipusat dan daerah, termasuk BUMN atau BUMD dalam mengatur tata laksana pelayanan umum dilingkungan instansinya masing-masing. Dalam pedoman Menpan tersebut dijelaskan pelayanan prima bagi instansi pemerintah memilik unsur-unsur sebagai berikut : Kesederhanaan dalam arti prosedur atau tata cara pelayanan umum diselenggarakan secara mudah, lancar tidak berbelit-belit, mudah dipahami dan mudah dilaksanakan. Kejelasan dan kepastian, dalam arti kejelasan dan kepastian prosedur, persyaratan, unit kerja pelaksana, hak dan kewajiban pemberi dan penerima pelayanan. Keamanan dalam arti proses dan hasil pelayanan umum dapat memberikan keamanan dan kenyamanan. Keterbukaan, wajib memberikan informasi agar mudah diketahui dan dipahami masyarakat. Efisiensi, dalam arti mempersyaratkan kelengkapan syarat administartif, keterpaduan, murah dan mudah. Ekonomi, dalam arti merata kepada seluruh masyarakat tanpa pengecualian. Keadilan, dalam arti merata kepada seluruh masyarakat tanpa pengecualian. Ketepatan waktu, dalam arti harus dapat diselesaikan menurut waktu yang telah ditetapkan.

Mengenai konsep organisasi telah banyak mendapat perhatian para ahli. Dalam tulisan ini mengacu kepada pandangan Huse dan Bowditch (Sutarto, $1990: 7$ ) yang menyatakan bahwa organisasi adalah sebuah sistem sosial, yaitu yang tersusun dari sejumlah sub sistem yang saling berhubungan, terbuka dan dinamis yang memiliki input, output, operasi, umpan balik dan batas, memilik berbagai tujuan dan sasaran dan adanya konflik. Dari pendapat tentang konsep organisasi seperti diatas, dapat dipahami bahwa organisasi pada dasarnya bukan sekedar kumpulan orang, atau pula bukan sekedar proses pembagian kerja tetapi lebih merupakan sebuah sistem saling pengaruh mempengaruhi antar sub sistem, baik orang maupun alat atau benda lainnya dalam kelompok yang bekerjasama untuk mencapai tujuan tertentu. Dengan demikian organisasi sebagai suatu sistem, didalamnya terdapat beberapa sub sistem yang saling berhubungan dan saling mempengaruhi satu dengan lainnya secara sinergis yang diarahkan untuk mencapai tujuan tertentu. Sebagai seuah sistem, organisasi memiliki komponen berupa input, komponen proses, komponen output, komponen feedback dari respon lingkungan. Dalam komponen input dapat berupa sumber daya meliputi manusia, material, mesin, metode, keuangan, pasar dan sebagainya. Sedangkan komponen proses meliputi aturan hukum, proses komunikasi, kepemimpinan, pengambilan keputusan, pengawasan skill, dan sebagainya. Komponen output adalah hasil (produk barang dan jasa) yang diperoleh dari input yang diproses sebelumnya. Sedangkan respon lingkungan dapat berupa tanggapan, kritik dan permintaan dari masyarakat terhadap output yang telah diciptakan.

Dilihat dari jenisnya, organisasi termasuk memiliki variasi yang sangat beragam. Lazimnya jenis yang bervariasi dari organisasi ini dapat dilihat dari tujuan dan keanggotaannya. Dari segi tujuan, ada organisasi yang mencari keuntungan dan ada yang berorientasi pelayanan. Dari segi keanggotaan, ada organisasi yang jumlah aktivitas anggotanya banyak dan rumit dan ada yang sedikit dan sederhana. Dalam pandangan Ansoff (Salusu, 2001 :12) salah satu jenis organisasi adalah jenis organisasi yang melayani lingkungan (Enviromental Serving Organization) yang disingkat ESO.Organisasi yang termasuk jenis ESO ini adalah perusahaan bisnis, rumah sakit, perguruan tinggi, organisasi keagamaan, rumah yatim piatu dan badan pemerintah yang memberikan pelayanan publik. Khususnya RSUD Kabupaten Sintang merupakan organisasi yang erorientasi kepada pelayanan jasa kesehatan masyarakat. Oleh karenanya, sebagai sistem, RSUD Kabupaten Sintang memiliki komponen input, proses, output dan feedback lingkungan yang semuanya itu saling berinteraksi dan saling mempengaruhi. 
Istilah persepsi pada dasarnya merupakan fungsi psikis dari manusia (Sarwono, 1976 : 39). Artinya persepsi merupakan hasil dari proses kejiwaan seseorang. Adapun proses kejiwaan itu berkenaan dengan pengenalan terhadap lingkungan yang ada disekitarnya. Menurut Kamus Besar Bahasa Indonesia dari Depdikbud (1990 : 675) persepsi mempunyai dua arti, yaitu : 1). Tanggapan atau penerimaan. 2). Proses seseorang mengetahui beberapa hal melalui panca inderanya. Sedangkan Thoha (1992 : 138) memberikan batasan persepsi sebagai " proses kognitif yang dialami oleh setiap orang didalam memahami informasi tentang lingkungannya, baik lewat penglihatan, pendengaran, penghayatan, perasaan dan penciuman."

Dari berbagai pengertian yang dikutip seperti diatas, dapat dipahami bahwa persepsi pada dasarnya merupakan hasil dari proses kejiwaan, dalam hal ini fungsi kognitif dari seseorang dalam upaya memahami atau mengetahui tentang obyekobyek yang ada dilingkungan sekitarnya. Karena persepsi berkaitan dengan cara mendapatkan pengetahuan tentang obyek, peristiwa, kejadian atau suatu benda tertentu, maka persepsi terjadi kapan saja selama adanya stimulus (rangsangan) yang menggerakan indera manusia. Dalam hal ini, dapat dimengerti bahwa persepsi lebih merupakan reaksi (respons) dari adanya rangsangan (stimulus) yang dihadapi seseorang. Apabila proses kognitif dalam upaya memahami berbagai obyek dilingkungan sekitar itu menyangkut tentang sekelompok orang atau masyarakat maka disebut dengan persepsi sosial. Dalam kaitannya dengan penelitian ini, dapat digambarkan bahwa persepsi masyarakat merupakan pola respon atau tanggaapan dari masyarakat terhadap adanya stimulus (rangsangan) berupa pemberian pelayanan kesehatan, baik pelayanan administratif maupun pelayanan medis oleh RSUD Kabupaten Sintang. Persepsi itu berupa pendapat atau pandangan dan harapan dari masyarakat terhadap tingkat kualitas pelayanan yang diberikan RSUD Kabupaten Sintang selama ini.

\section{METODE PENELITIAN}

Memperhatikan masalah penelitian dan tujuan yang ingin dicapai, maka rancangan atau jenis penelitian yang dipilih dalam penelitian ini adalah jenis penelitian deskriptif. Yang dimaksud penelitian deskriptif adalah suatu jenis penelitian yang menggambarkan secara cermat terhadap suatu jenis fenomena sosial tertentu dalam jangka waktu tertentu. Metode pengumpulan data yang dipergunakan dalam penelitian ini adalah studi kepustakaan dan studi lapangan serta alat pengumpulan data pedoman observasi dan pedoman wawancara.

Subyek penelitian adalah masyarakat dikota Sintang secara langsung maupun tidak langsung pernah berhubungan dengan pelayanan kesehatan di RSUD Kabupaten Sintang. Dalam penelitian ini juga menggunakan informan kunci, yaitu Direktur RSUD dan Kasi Pelayanan RSUD dengan menjaring data melalui instrumen pedoman wawancara. Teknik analisis data yang digunakan adalah analisis kualitatif, artinya setelah data terkumpul diklasifikasikan dan selanjutnya data tersebut diolah dan pengolahan data tersebut lebih banyak menggunakan ungkapan-ungkapan kalimat sebagai interprestasi dari data yang diolah tersebut.

\section{HASIL PENELITIAN DAN PEMBAHASAN}

\section{Kinerja Pelayanan Administratif di RSUD Kabupaten Sintang}

Dalam upaya memberikan pelayanan publik diidang kesehatan, RSUD Kabupaten Sintang selaku institusi pemerintahan terlebih dahulu menyelenggarakan pelayanan administratif berupa pencatatan identitas pasien, pendaftaran pasien,pembayaran jasa medis dan sebagainya. Hal ini dilakukan selain untuk memenuhi persyaratan administratif yang telah ditentukan, tetapi juga merupakan bagian dari mekanisme pelayanan publik yang berlaku dibidang pelayanan kesehatan pada umumnya. Selain itu pula, pelayanan administratif di RSUD Kaupaten Sintang merupakan bagian dari totalitas pelayanan kesehatan yang diberikan oleh RSUD kepada masyarakat. Oleh karena itu, kualitas pelayanan administratif ini akan mempengaruhi secara keseluruhan kualitas pelayanan publik yang diberikan oleh RSUD Kabupaten Sintang.

Terdapat beberapa indikator untuk menilai penyelenggaraan pelayanan administratif di RSUD Kabupaten Sintang, yaitu kecepatan pelayanan, ketepatan pelayanan dan ketelitian pelayanan. Tiga indikator ini akan menjadi acuan dalam menilai sejauh mana kualitas pelayanan administratif di RSUD Kabupaten Sintang. Sedangkan menurut hasil wawancara dengan Direktur RSUD bahwa pelaksanaan pendaftaran pasien telah dilaksanakan secara maksimal meskipun tidak dapat dipungkiri ada beberapa kendala yang terjadi, misalnya kendala yang bersifat teknis. Sedangkan hasil wawancara dengan Kasi Pelayanan RSUD Kabupaten Sintang bahwa pelayanan adminitratif pendaftaran pasien diloket dilakukan secara tersentral, yaitu hanya ada satu loket pendaftarandengan maksud agar tertib administrasi. Sedangkan dalam pelaksanaan pendaftaran pasien mengacu kepada ketentuan pelayanan prima di RSUD Kabupaten Sintang.

Mengenai data tentang tanggapan terhadap kecepatan pelayanan administratif yang dierikan oleh petugas RSUD Kabupaten Sintang dapat dikemukan bahwa pelayanan administratif yang diberikan petugas RSUD sudah dianggap baik dan 
cepat. Menurut hasil wawancara dengan Direktur dan Kasi Pelayanan RSUD Kaupaten Sintang, bahwa selama ini pelayanan administratif sudah cukup memadai, dalam arti sesuai dengan ketentuan yang ada.

Mengenai data dalam pemberian pelayanan administratif di RSUD Kabupaten Sintang, diketahui bahwa pelayanan administrasi rumah sakit belum pernah terjadi kesalahan data untuk pasien dengan berbagai macam jenis penyakit. Berdasarkan hasil wawancara dengan Direktur dan Kasi Pelayanan bahwa kesalahan dalam pelayanan administratif memang pernah teradi, namun dengan jumlah yang sedikit. Dan bentuk kesalahan tersebut juga tidak prinsipil, dalam arti sebatas kesalahan tatausahaan, seperti salah nama pasien, arsip yang belum tertata baik dan sebagainya.

Mengenai data tentang ketelitian pelayanan administratif di RSUD Kabupaten Sintang , diperoleh keterangan bahwa bahwa ketelitian pelayanan pasien sudah sangat baik dan teliti. Mengenai data tentang prilaku petugas pelayan administratif di RSUD Kabupaten Sintang , diperoleh keterangan bahwa terkesan cukup ramah pelayanan administratif di RSUD Kabupaten Sintang. Berdasarkan hasil wawancara dengan Derektur RSUD Kabupaten Sintang tarif pemberian pelayanan administratif di RSUD mengacu kepada Pengaturan Daerah Nomor 06 tahun 2000 seingga penetapan tarif telah memiliki standar yang jelas dan bukan dilakukan secara tidak jelas. Dalam pandangan Direktur RSUD Kabupaten Sintang tarif pelayanan administratif yang adacukup memadai dan sesuai dengan kemampuan masyarakat. Disaat yang sama informasi yang diberikan oleh Kasi Pelayanan juga relatif tidak bereda dengan yang dismpaikan oleh Direktur RSUD.

Jika mengacu kepada data yang telah terkumpul dan hasil pengolah data yang berasal dari angket kepada responden dan wawancara dengan responden tehadap kualitas pelayanan administratif di RSUD Kabupaten Sintang, maka pada umumnya kualitas pelayanan administratif di RSUD Kabupaten Sintang masih relatif rendah. Hal ini dapat dilihat dari indikatorseperti tanggapan pendaftaran pasien, kecepatan pelayanan administratif, terjadinya kesalahan pelayanan administratif, prilaku petugas administratif dan biaya administratif yang pada umumnya diakui responden masih rendah dan belum memuaskan serta belum berjalan sebagaimana yang diharapkan. Selain itu pula para informan, yaitu Direktur RSUD dan Kasi Pelayanan RSUD Kabupaten Sintang berdasarkan indikator yang ada memang mengakui masih belum optimalnya pelayanan administratif yang diberikan RSUD kepada masyarakat.
Jika dilihat secara lebih cermat, masih rendahnya kualitas pelayanan administratif di RSUD ini dapat terjadi karena adanya beberapa faktor yang saling berhubungan satu dengan lainya seperti berikut ini:

Pertama: masih lemahnya komitmen organisasi RSUD untuk benar-benar mewujudkan kualitas pelayanan administratif di RSUD terhadap masyarakat. Yang dimaksud dengan komitmen disini adalah kemauan yang teguh di imbangi dengan kemampuan untuk mewujudkan kualitas kerja (administratif) RSUD dalam tataran yang operasional. Jika ada komitmen tersebut, tampaknya hanya sebatas wacana yang bersifat individual dan belum menyentuh kepada kehendak organisasi secara keseluruhan untuk diwujudkan secara konkrit. Padahal komitmen ini sangat penting menghadirkan kualitas, seperti yang dikemukakan oleh Swiss (dalam Salusu,200: 459) kualitas menuntut komitmen organisasi secara terpadu yang telah diunkapakan dalam Bab Kajian Pustaka.

Kedua: dari masih rendahnya komitmen ini, melahirkan kurangnya pengawasan internal di RSUD, sehingga para petugas dalam memberikan pelayanan masih belum optimal. Kelemahan pegawas internal ini menjadi celah yang cukup lebar terjadi berbagai kesalahan atau kekeliruan dalam pemberikan pelayanan administratif sehingga padagiliranya mempengaruhi kinerja pelayanan secara keselurahan. Pegawasan internal yang masih relatif terbatas selain akan merendahkan standar pelayanan tetapi juga berakibat lemahnya terobosan baru untuk meningkatkan pelayanan yang melebihi standar yang ada.

Ketiga: selain itu pula, faktor penetapan loket yang sentralisasi, yaitu hanya ada satu loket pendaftaran dan pembayaran pasien, juga memberikan andil yang cukup besar sehingga pelayanan administratif di RSUD kurang mampu memenuhi kebutuhan pelayanan yang semakin meningkat. Dengan sistem loket seperti ini selain sangat lamban dan melahirkan antrian yang cukup panjang, tetapi juga membuat prosedur kerja yang rumit serta berorientasi pada prosedur formalisitik yang kaku. Padahal dalam pandangan Swiss yang telah dikutip dalam Bab Kajian Pustaka kualitas kerja suatu organisasi mempersyaratkan perbaikan masukan dan proses secara kontinyu. Artinya kualitas kerja akan terwujud apabila adanya peraikan proses (prosedur) sehingga akan mempengaruhi hasil akhir. Apalagi ada sebuah prinsip dalam manajemen mutu terpadu bahwa meningkatkan kualitas melalui manajemen proses. Oleh karena itu, untuk dimasa mendatang diperlukan adanya perubahan penataan lokrt menjadi yang bersifat desentralistik dengan 
memberikan jumlah loket yang lebih banyak dengan diiringi peminaan kepada petugas loket sesuai tuntutan tugas yang diemban. Hal ini juga sejalan dengan salah satu unsur pelayanan prima yang dikemukakan dalam Pedoman Menpan yaitu kesederhanaan dalam arti prosedur pelayanan umum dilakukan secara mudah, lancar, tidak berbelit-belit, mudah dipahami dan dilaksanakan.

Keempat: faktor lain yaitu peminaan sumber daya manusia (pegawai yang bertugas melakukan pelayanan administraitif) yang belum optimal dari aspek pelaksanaan tugas administratif di RSUD Kabupaten Sintang. Dalam hal ini selain belum memhami tugas dengan baik, tertanamnya kebiasan kerja yang buruk dan kurang cepat merespon dan mempelajari sesuatu yang baru menjadi akar masalah sehingga pegawai di RSUD menunjukan kinerja yang kurang optimal. Padahal seperti pendapat Mali yang dikutip dalam Bab Kajian Pustaka diantara beberapa pendoman kerja yang berorientasi kualitas adalah memahami pekerjaan yang baik, adanya kebiasaan kerja yang baik dan adanya kemauan untuk mempelajari sesuatu yang baru dalam bekerja.

\section{Kualitas Pelayanan Medis di RSUD Kabupaten Sintang.}

Sebagaimana layaknya sebuah rumah sakit, RSUD Kaupaten Sintang mengemban tugas pokok untuk memerikan pelayanan medis berupa aktivitas diagnosa penyakit, penyembuh penyakit, perawatan dan sebagainya kepada pasien. Dalam memberikan pelayanan medis ini sangat didukung tersedianya tenaga medis dan prasarana yang memadai sehingga dapat memerikan kepuasan bagi pengguna jasa RSUD. Ketepatan diagnosa, penyembuhan penyakit serta ketelitian dan kecepatan jasa medis guna mengetahui tingkat kualitas pelayanan medis yang telah diberikan RSUD Kabupaten Sintang. Adapun data kehadiran tenaga medis, khususnya dokter dalam memberikan pengobatan RSUD Kabupaten Sintang, sangat rajin kehadiran dokter dalam memberikan pengobatan di RSUD Kabupaten Sintang. Berdasarkan hasil wawancara dengan Direktur RSUD Kabupaten Sintang bahwa tingkat kehadiran para Dokter cukup rajin dalam melaksanakan tugasnya memerikan pengobatan pada pasien. Pendapat senada juga dikemukakan oleh Kasi Pelayanan RSUD Kabupaten Sintang dengan alat pengawasnya adalah absen kehadiran tenaga medis yang ada di RSUD. Meskipun ada beberapa tenaga medis yang tidak hadir saat tugas juga diakui oleh Kasi Pelayanan namun dalam intensitas yang minim.

Perilaku tenaga medis, baik dokter maupun tenaga medis lainnya dalam memberikan pelayanan medis di RSUD Kaupaten Sintang, diperoleh keterangan bahwa sangat ramah perilaku para medis dalam memerikan pelayanan medis di RSUD Kabupaten Sintang. Mengenai data tentang pengobatan yang diberikan para medis terhadap penyakit yang dialami pasien di RSUD Kabupaten Sintang, diperoleh keterangan ahwa responden yang menjawab sangat baik pengobatan yang diberikan para medis terhadap penyakit yang dialami pasien di RSUD Kabupaten Sintang sudah baik dan sangat memuaskan. Tingkat ketelitian para medis memeriksa penyakit dialami pasien di RSUD Kabupaten Sintang, diperoleh keterangan bahwa mereka sangat teliti dalam memeriksa penyakit pasien di RSUD Kaupaten Sintang. Adapun data tentang tingkat kesalahan atau kekeliruan dalam memberikan obat kepada pasien di RSUD Kabupaten Sintang, diperoleh keterangan bahwa belum pernah terjadi kesalahan atau kekeliruan dalam memberikan obat di RSUD Kaupaten Sintang. Mengenai data tentang tingkat ketersedian sarana dan prasarana medis di RSUD Kabupaten Sintang, diperoleh keterangan bahwa sudah dianggap lengkap ketersedian sarana dan prasarana medis di RSUD Kabupaten Sintang. Berdasarkan hasil wawancara dengan Direktur dan Kasi Pelayanan RSUD Kaupaten Sintang masih mengalami keterbatasan sarana dan prasarana medis sehingga berakibat belum optimalnya pelayanan medis yang diberikan. Sehingga anyak pasien yang diberikan rujukan ke Pontianak karena keterbatasan sarana dan prasarana yang dimiliki.

Kualitas pelayanan medis di RSUD Kabupaten Sintang masih relatif rendah. Hal ini dapat dilihat dari indikator seperti tanggapan kehadiran dokter, prilaku tenaga medis, pengobatan yang diberikan, tingkat kesalahan pemberian obat, ketersedian sarana dan prasana medis yang pada umumnya diakui responden masih belum memuaskan dan belum berjalan sebagaimana yang diharapkan. Selain itu pula para informan, yaitu Direktur RSUD dan Kasi Pelayanan RSUD Kabupaten Sintang berdasarkan indikator yang ada memang mengakui masih belum maksimalnya pelayanan medis yang dierikan kepada masyarakat. Menurut hemat peneliti terjadinya kualitas pelayanan medis yang relatif sudah baik akan tetapi perlu ditingkatkan di RSUD antara lain melalui beberapa aspek penting, yaitu:

Pertama: terbatasnya sarana dan prasana medis yang dibutuhkan untuk menunjang pelayanan medis di RSUD Kabupaten Sintang. Dengan keterbatasan sarana dan prasarana selain optimalisi pelaksanaan tugas kurang berjalan tetapi juga menjadikan para medis kurang temotivasi dalam pelaksanaan tugas. Dalam ilmu manajemen pada 
umumnya salah satu sumber daya mendukung pelaksanaan tugas adalah tersedianya sarana dan prasarana yang memiliki aspek kualitas dan kuantitas memadai. Apalagi melihat tuntutan pekerjaan medis di RSUD, keberadaan sarana dan prasarana tertentu yang bersifat spesifik sangat menentukan tingkat kualitas pelayanan masyarakat. Jika dikaitkan dengan adanya peningkatan tarif di RSUD, maka pengadaan sarana dan prasarana penujang kesehatan juga harus lebih ditingkatkan sesuai dengan harapan masyarakat. Sebab, bagi masyarakat dengan meningkatanya tarif tersebut harus juga diimbangi dengan peningkatan perbaikan pelayanan kesehatan yang diberikan.

Kedua: selain itu pula masih lemahnya pengawasan internal yang bersifat medis di RSUD, sehingga para petugas medis (Dokter, Perawat, Bidan dan Mantri Kesehatan) dalam memberikan pelayanan masih belum aik dan belum memuaskan. Ika merujuk pada makna hakiki pengawasan yaitu untuk menjamin pelaksanaan pekerjaan tidak menyimpang, mengalami kekeliruan dan kesalahandari rencana yang ada, maka pelaksanaan pengawasan harus terus dilaksanakan san ditingkatkan mutunya. Pengawasan individual, pengawasan fungsional dan pengawasan melekat yang ada selama ini harus dijalankan secara konsisten, tepat dan berkesenambungan di RSUD. Dalam hal ini komitmen dari unsur pimpinan di RSUD masih perluuntuk ditingkatkan agar dapat mendukung pelaksanaan pengawasan yang sehat dan bermanfaat.

Ketiga: dan juga tampaknya etika profesi bagi tenaga medis di RSUD selain perlu ditegakan tetapi juga harus menjadi kesadaran internal dari seluruhan tenaga medis di RSUD Kabupaten Sintang. Sebab, para tenanga medis itu pada dasarnya profesi yang mengemban tugas mulia demi penyelamatan kemanusiaan dan ukan sematamata bernilai ekonomis. Jika kita mengacu kepada kode etik versi ASPA yang dikutip Kumorotomo dalam Bab Kajian Pustaka selain pelayanan kepada masyarakat menuntut kepekaan, tetapi juga hati nurani memegang peranan penting dalam melaksanakan tugas pelayanan. Dua hal ini secara subtansial sebenarnya berkaitan dengan kode eik profesi yang bersifat umum harus dipegang siapapun yang bertugas seagaiamana pelayanan publik termasuk para tenaga medis di RSUD.

Apalagi dalam pandangan Swiss bahwa konsumen adalah penentu dari kualitas akhir, sehingga perhatian terhadap konsumen melalui penterjemahan prinsip-prinsip kode etik profesi adalah sesuatu yang tidak dapat ditawar-tawar. Jika merujuk pendapat Kaufman tenaga medis di RSUD sangat perlu memperhatikan kembali ciri-ciri pelayanan publik yang harus diberikan pemerintah seperti mendahulukan kepentingan umum, mempermudah urusan publik, dan memberikan kepuasan kepada konsumen. Jika ciri-ciri pelayanan ini tetanam secara mendalam di hati nurani para tenaga medis di RSUD akan dapat meningkat lebih baik.

\section{KESIMPULAN DAN SARAN}

Adapun kesimpulan yang dapat diajukan dalam penelitian ini adalah sebagai berikut; Bahwa kinerja pelayanan RSUD Kabupaten Sintang terhadap pelayanan publik secara umum sudah baik. Adapun kualitas pelayanan administratif di RSUD sudah baik. Saran agar petugas pelayan administratif, baik petugas loket, petugas pemerian obat, petugas ketatausahaan (arsip) diberikan pembinaan yang berhubungan dengan pelaksanaan tugas melalui pendidikan dan pelatihan khusus sehingga keahlian dan profesionalisme petugas tersebut akan bertambah tinggi. Agar pelayanan administratif lebuh efektif, efisien dan cepat, salah satu alternatif yang memungkinkan diambil adalah dengan menerapkan sistem loket yang desentralisasi, yaitu menyediakan beberapa loke administratif di beberapa tempat di RSUD Kabupaten Sintang. Guna mendukung peningkatan kualitas pelayanan medis di RSUD Kabupaten Sintang maka penambahan dan peningkatan sarana dan prasarana medis di RSUD Kabupaten Sintang. kepada unsur Pimpinan, terutama Direktur RSUD Kabupaten Sintang agar lebih meningkatkan pengawasan internal dengan menerapkan konsep Total Cuality Control di seluruh jenjang pelayanan yang ada terutama dalam aspek manajemen perkantoran di RSUD kabupaten Sintang. 
8. Fokus, Fokus, Volume 17, Nomor 1, Maret 2019, hlm. 1 - 8

\section{DAFTAR PUSTAKA}

Departemen Pendidikan dan Kebudayaan Republik Indonesia. 1990 . KamusBesar BahasaIndonesia. Jakarta: Balai Pustaka.

Gaspersz, V. 2001. TotalQualityManagement. Jakarta: Gramedia Pustaka Utama.

Gibson et al. 1995. Organisasi. Jakarta: Erlangga.

Kumorotomo, W. 2001. EtikaAdministrasiNegara. Jakarta: Gramedia Pustaka Utama.

Nawawi, H.1983. MetodePenelitianBidangSosial. Yogyakarta: Gajah Mada Press.

Ryass Rasyid, M.1996. MaknaPemerintah,TinjauanDariSegiEtika dan Kepemimpinan. Jakarta: Yasraf Watampo.

Saluu, J. 1996. PengambilanKeputusanStartejik. Jakarata: Gramedia Widiasarana.
Sarwono. S. W. 1976.

PengaatarUmumPsikologi. Jakarta : Bulan Bintang.

Singarimbun, M. dan Effendi, S. 1989.

MetodePenelitianSurvei. Jakarta : LP3ES

Soetopo. 1999. PelayananPrima. (Bahan Diklat ADUM). Jakarta : LAN.

Sugiyono. 2001. MetodePenelitianAdministrasi. Bandung: Alfabeta.

Supriyatna, T. 1996.

AdministrasiBirokrasiPelayananPublik. Jakarta : Nimas Mutlima.

Thoha, M. 1992. Prilaku Organisasi,Konsep Dasar dan Aplikasinya.

Jakarta: Rajawali. 